\title{
FACTORS INFLUENCING THE PRODUCTIVITY OF EXCAVATION WORKS FOR CONSTRUCTION PROJECTS IN JORDAN
}

\author{
Dr. Orabi Al Rawi
}

Civil Engineering Department, Isra University, Amman, Jordan

\section{Dr. Ibrahim Farouq Varouqa}

Civil Engineering Department, Isra University, Amman, Jordan

\section{Dr. Ra'ed Al-muhanna}

Civil Engineering Department, Isra University, Amman, Jordan

Eng. Ala' Diab Amer

Civil Engineering Department, Isra University, Amman, Jordan

\begin{abstract}
This paper is focused on studying the factors affecting the productivity of excavation works in Jordan. In order to investigate this target, a questionnaire was designed considering the most important factors that were proposed in the literature, then distributed to 55 of experts and contractors. Accordingly, the collected data was analyzed using SPSS software in order to evaluate those factors and to arrange them based on their importance sequence.

In general, several major factors affect the productivity of excavation works in construction projects. In this research, five of those factors were selected and studied, evaluated, and concluded to be the most major factors that could influence the productivity of excavation works for construction projects in Jordan, and could significantly affect the cost and time of carrying out the project. Accordingly, the results of this research showed that the increase in the productivity for excavation works is related to taking into account the factors recommended according to their priority, in which the first of these was the "the types and readiness of the excavation machines", followed by (in descending order) "the geological nature of the site", "the project site investigation", "the technical expertise specialized in carrying out excavation works", and "the financial liquidity and the payment of dues".
\end{abstract}

Keywords: Excavation Works, SPSS Software, Productivity, Questionnaire

Cite this Article: Orabi Al Rawi, Ibrahim Farouq Varouqa, Ra'ed Al-muhanna and Ala' Diab Amer, Factors Influencing the Productivity of Excavation Works for Construction Projects in Jordan, International Journal of Civil Engineering and Technology (IJCIET), 12(4), 2021, pp. 62-72.

https://iaeme.com/Home/issue/IJCIET?Volume=12\&Issue $=4$ 


\section{INTRODUCTION}

As commonly known, an excavation means the removal of a soil from a proposed site (using conventional tools, machinery, or explosives) in order to prepare its land for construction (i.e., in buildings, to reach the recommended foundation level). Generally, various types of excavations may encounter the site engineer in the field of construction. Some of these are: topsoil excavations, drainage excavations, channel excavations, basement excavations, trench excavations, footing excavations, roadway excavations, and underground excavations.

Several types of soil excavation tools and machines were used in the field of construction including:

- Hand tools, such as: spade, shovel, hoe, trowel, rake, pick axe, and mattock.

- Machinery tools, such as: tracked excavator, wheeled excavator, backhoe excavator, bulldozer, dragline excavator, power shovels, crawler's excavator, and rock breakers.

Referring to the available literature, several (general) factors could affect the performance of an excavator, some of these are:

- Proper equipment selection.

- Site conditions.

- Cycle time.

- Bucket size.

- Angle of swing.

- Repairs and maintenance of equipment.

- Operator's skill.

Regardless the type of excavation, it was observed that the productivity of such activity plays a major part in estimating the cost and time period of the project implementation.

In general, the term productivity refers to the measure of the rate at which work is performed. It is the ratio of production output to what is required to produce it, and the measure of productivity is defined as a total output per one unit of a total input. In construction, the output is usually expressed in weight, length, or volume, while the input resource is expressed in cost of labor or man-hours. Several standards are available in the construction industry as reference values for purposes of construction cost estimation. These standards may differ in values but most are similar in principle [3].

It is obviously that the rapid growth in the construction industry during the recent years in Jordan, and the vastness of the current constructions leaded to remove large quantities of soil from those sites; and accordingly, these operations (excavations) considered as a substantial part of the project, and could affect its total cost and its period of construction. These operations are relatively repetitive and machine oriented, being carried out through different circumstances and variables that could affect the productivity related to these operations [5].

Through the preliminary investigation in the Jordanian labor market, specifically those related to excavation works, several problems have been noticed regarding the productivity of these works in a lot of sites, which encouraged a comprehensive investigation into the above purpose in order to understand the most factors affecting the productivity of excavation works in Jordan. 
Orabi Al Rawi, Ibrahim Farouq Varouqa, Ra'ed Al-muhanna and Ala' Diab Amer

\section{RESEARCH METHODOLOGY}

The methodology of this research was conducted considering the following steps:

- Review for previous studies that were focused on the most important factors affecting the productivity of excavation works in construction projects.

- Determining the most important factors affecting the productivity of excavation work, taking into account what was indicated in the literature and also through the researcher's preliminary investigations.

- Designing for the questionnaire regarding the above factors, and distributing it to a number of experts and contractors.

- Collecting for the results of questionnaire and analyzing for data using SPSS software.

- Submitting for the findings and recommendations.

\section{LITERATURE REVIEW}

Several previous studies were reviewed for the purpose of understanding the factors affecting the productivity of excavation works. In this paper, a summary of factors affecting the productivity for each study (reference) was documented in Table 1.

Table 1: Summary of Previous Studies that Focused on the Factors Affecting the Productivity of

Construction Projects

\begin{tabular}{|c|c|}
\hline $\begin{array}{l}\text { Reference } \\
\text { No. }\end{array}$ & Factors Affecting the Productivity of Construction Projects \\
\hline [9] & Incentives and performance of public safety \\
\hline [6] & $\begin{array}{l}\text { The technology used and the technologies needed to monitor all phases of the } \\
\text { project }\end{array}$ \\
\hline$[2]$ & The presence of specialized technicians and previous experience \\
\hline [17] & The infrastructure surrounding the project site \\
\hline [16] & $\begin{array}{l}\text { Financial liquidity and payment of dues, the experiences of the consulting } \\
\text { authority overseeing the excavation work, and the readiness of the executing party } \\
\text { for the excavating work }\end{array}$ \\
\hline [8] & Types and readiness of the excavation machines \\
\hline [18] & General conditions surrounding the project site \\
\hline [13] & Consulting experiences supervising of the excavation works and financial liquidity \\
\hline [19] & $\begin{array}{l}\text { Technical expertise specialized in carrying out excavation works and consulting } \\
\text { experiences supervising of the excavation works }\end{array}$ \\
\hline [14] & Types and readiness of the excavation machines \\
\hline [10] & Project site investigation \\
\hline [11] & Environmental conditions surrounding the project site \\
\hline [20] & $\begin{array}{l}\text { Types and readiness of the excavation machines and technical expertise } \\
\text { specialized in carrying out excavation works }\end{array}$ \\
\hline [15] & $\begin{array}{l}\text { Preparing the excavation executing agency for general requirements before } \\
\text { commencing implementation work and effect of the efficiency of excavation } \\
\text { executing agency }\end{array}$ \\
\hline [7] & Geological nature of the site and the number of the used machines \\
\hline [1] & Project site investigation and effect of caves in the project site \\
\hline [12] & effect of periodic maintenance of various excavation machines \\
\hline [4] & Incentives \\
\hline
\end{tabular}




\section{RESEARCH HYPOTHESIS}

The hypotheses of this research took into account the validity of the following:

- Null Hypothesis (H0): which means that the factors affecting the productivity of excavation works for construction projects in Jordan is insignificant and has no effect on the cost and time of a project, and therefore everything is performed under standards and regulations, so there is no need for further developments.

- Alternative Hypothesis (H1): which assures that there is a real problem faced by a large part of construction projects in Jordan concerning the productivity of excavation works, and it is necessary to highlight for the factors influencing the productivity of these works, and if this hypothesis is valid, therefore what are the necessary means needed to address this problem.

\section{QUESTIONNAIRE}

As mentioned before, the methodology of this research included designing a questionnaire that mainly consists of the factors that will be investigated, in addition to some general information for the person who completes the questionnaire. This questionnaire was distributed to a set of 55 project managers, consultants, contractors and subcontractors.

To measure the stability of this questionnaire, internal consistency was used through Cronbach alpha. The values of all reliability coefficients showed the range $(0.949-0.987 \%)$, which means that they are generally higher than 0.70 , which is acceptable in researches and studies. Table 2 indicates the reliability coefficients using Cronbach Alpha.

Table 2: Reliability Coefficients Using Cronbach Alpha for the Questionnaire

\begin{tabular}{|c|l|c|c|}
\hline $\begin{array}{c}\text { Number } \\
\text { of } \\
\text { Variables }\end{array}$ & \multicolumn{1}{|c|}{$\begin{array}{c}\text { Most Important Factors } \\
\text { (Proposed from Literature) }\end{array}$} & $\begin{array}{c}\text { Number of } \\
\text { Statements }\end{array}$ & $\begin{array}{c}\text { Cronbach } \\
\text { Alpha }\end{array}$ \\
\hline A & Project site investigation & 9 & 0.987 \\
\hline B & Types and readiness of the excavation machines & 7 & 0.965 \\
\hline C & $\begin{array}{l}\text { Technical expertise specialized in carrying out } \\
\text { excavation works }\end{array}$ & 7 & 0.985 \\
\hline D & Financial liquidity and the payment of dues & 3 & 0.949 \\
\hline E & Geological nature of the site & 3 & 0.971 \\
\hline
\end{tabular}

\section{SIZE OF THE RESEARCH SAMPLE}

Table 3 shows that $60 \%$ of respondents have more than 10 years of experience, while $40 \%$ have ten years of experience or less. Whereas, Table 4 shows that $41.8 \%$ of respondents have implemented more than 10 projects, while $58.2 \%$ have implemented 10 projects or less.

Table 3 Sample Distribution by Years of Experience

\begin{tabular}{|l|c|c|}
\hline \multicolumn{1}{|c|}{ Experience } & Frequency & $(\mathbf{\% )}$ \\
\hline 1-5 years & 9 & 16.4 \\
\hline 6-10 years & 13 & 23.6 \\
\hline More than 10 years & 33 & 60 \\
\hline Total & 55 & 100 \\
\hline
\end{tabular}


Orabi Al Rawi, Ibrahim Farouq Varouqa, Ra'ed Al-muhanna and Ala' Diab Amer

Table 4 Distribution of Sample by Number of Projects

\begin{tabular}{|l|c|c|}
\hline \multicolumn{1}{|c|}{ Number of Projects } & Frequency & $(\mathbf{\% )}$ \\
\hline 1-5 projects & 17 & 30.9 \\
\hline 6-10 projects & 15 & 27.3 \\
\hline More than 10 projects & 23 & 41.8 \\
\hline Total & 55 & 100 \\
\hline
\end{tabular}

\section{RESULTS AND DISCUSSION}

The results of this research were obtained based on the analysis of the data received from the questionnaire using SPSS software. These results are presented in this paper in the form of responses to several of the main items as indicated in the following sections and tables. It should be noted that the responses were evaluated according to the five-point Likert scale as shown in Table 5; whereas the importance level of responses for each investigated item was classified as shown in Table 6.

Table 5: Five Point Likert Scale

\begin{tabular}{|c|c|c|c|c|}
\hline $\begin{array}{c}\text { Very } \\
\text { Low }\end{array}$ & Low & Medium & High & $\begin{array}{c}\text { Very } \\
\text { High }\end{array}$ \\
\hline 1 & 2 & 3 & 4 & 5 \\
\hline
\end{tabular}

Table 6 Criteria of Importance Level for Responses in Each Factor

\begin{tabular}{|c|l|}
\hline Range of Values & \multicolumn{1}{|c|}{ Level of Importance } \\
\hline $1.00-1.80$ & Very Low \\
\hline $1.81-2.61$ & Low \\
\hline $2.62-3.42$ & Medium \\
\hline $3.43-4.23$ & High \\
\hline $4.23-5.00$ & Very High \\
\hline
\end{tabular}

Table 7 shows the mean, standard deviation, ranking and importance level for each investigated factor in the questionnaire.

Table 7 Mean, Standard Deviation, Ranking and Importance Level for Each Factor

\begin{tabular}{|l|c|c|c|c|c|}
\hline \multicolumn{1}{|c|}{ Factors } & $\begin{array}{c}\text { Number of } \\
\text { Items }\end{array}$ & Mean & $\begin{array}{c}\text { Standard } \\
\text { Deviation }\end{array}$ & Ranking & $\begin{array}{c}\text { Importance } \\
\text { Level }\end{array}$ \\
\hline $\begin{array}{l}\text { Types and readiness of } \\
\text { excavation machines }\end{array}$ & 7 & 4.1039 & 0.75815 & 1 & High \\
\hline Geological nature of the site & 3 & 4.0727 & 0.96586 & 2 & High \\
\hline Site investigation for projects & 9 & 4.0061 & 0.98396 & 3 & High \\
\hline $\begin{array}{l}\text { Technical expertise in carrying } \\
\text { out excavation works }\end{array}$ & 7 & 3.6831 & 0.94708 & 4 & High \\
\hline $\begin{array}{l}\text { Financial liquidity and the } \\
\text { payment of dues }\end{array}$ & 3 & 3.6788 & 1.03232 & 5 & High \\
\hline \multicolumn{1}{|c|}{ Total } & 3.90892 & 0.93747 & \multicolumn{2}{|c|}{ High } \\
\hline
\end{tabular}

Table 7 indicates that the factor (Types and readiness of the excavation machines) with a mean (4.1039), and a standard deviation 0.75815 ranks first, while the factor (Geological nature of the site) with a mean (4.0727) and a standard deviation 0.96586 ranks second. The table also shows that the factor (A project site investigation) with a mean (4.0061) and a standard deviation 0.98396 ranks third, and the factor (Technical expertise specialized in carrying out excavation works) with a mean of (3.6831) and a standard deviation 0.94708 ranks fourth. And further, the factor (Financial liquidity and the payment of dues) with a mean (3.6788) and a standard deviation 1.03232 ranks fifth. 


\section{STATISTICAL HYPOTHESIS TESTING}

Statistical hypothesis testing is used to check whether a result is statistically significant or not. In this test, the probability of obtaining a result "equal to" or "more extreme" than what was actually observed is defined as the p-value. In general, before the test is conducted, the significance level of the test is selected $(5 \%$ or $1 \%)$ and namely as ( $\alpha$-alpha). Accordingly, if the $p$-value is less than or equal to the selected significance level ( $\alpha$-alpha), therefore the test suggests that the observed data are conflicted with the null hypothesis, and hence the null hypothesis should be rejected. Furthermore, a $5 \%$ or lower p-value is considered statistically significant, which means that the finding has $95 \%$ or more probably true. Accordingly, a sample size of 55 (used in this research) is large enough to test the hypothesis, where the population distribution is roughly bell-shaped (Normal Distribution). In general, the following sections include a proof for which of the mentioned hypothesis is valid include a proof for which of the mentioned hypothesis is valid.

\section{ANALYZING DATA FOR THE INVESTIGATED FACTORS}

The analysis regarding the investigated factors are listed in the following tables. The first of these is analyzing data for the factor "Types and readiness of the excavation machines" is shown in Table 8. This table indicates that the Chi-Square test is statistically significant for all elements (where the p-value is less than 0.05). This shows that there are significant differences in responses toward elements. Therefore, the results of this group can be generalized to the study population.

Table 8: Responses Towards "Types and Readiness of Excavation Machines"

\begin{tabular}{|c|c|c|c|c|c|c|c|c|c|c|c|c|c|c|}
\hline$\dot{\mathbf{Z}}$ & 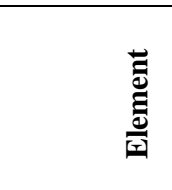 & & $\begin{array}{l}3 \\
\frac{3}{0} \\
\frac{3}{0} \\
0\end{array}$ & $\begin{array}{l}a \\
3 \\
0\end{array}$ & 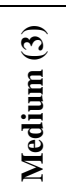 & 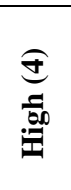 & 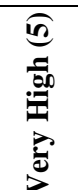 & $\stackrel{5}{0}$ & 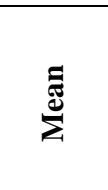 & 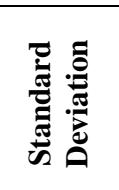 & 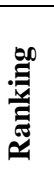 & 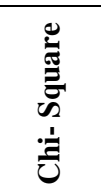 & $\begin{array}{l}\frac{9}{E} \\
\frac{0}{\pi} \\
\vdots\end{array}$ & 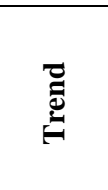 \\
\hline \multirow[b]{2}{*}{1} & \multirow{2}{*}{$\begin{array}{l}\text { Number of } \\
\text { used } \\
\text { machines }\end{array}$} & No. & 0 & 0 & 2 & 8 & 45 & 55 & \multirow[b]{2}{*}{4.7818} & \multirow[b]{2}{*}{0.49781} & \multirow[b]{2}{*}{1} & \multirow[b]{2}{*}{59.164} & \multirow[b]{2}{*}{0.000} & \multirow{2}{*}{$\begin{array}{l}\text { Very } \\
\text { High }\end{array}$} \\
\hline & & $\%$ & 0 & 0 & 3.6 & 14.5 & 81.82 & 100 & & & & & & \\
\hline \multirow{2}{*}{2} & \multirow{2}{*}{$\begin{array}{l}\text { Types of used } \\
\text { machines }\end{array}$} & No. & 0 & 2 & 10 & 20 & 23 & 55 & \multirow{2}{*}{4.1636} & \multirow{2}{*}{0.85556} & \multirow{2}{*}{4} & \multirow{2}{*}{20.127} & \multirow{2}{*}{0.000} & \multirow{2}{*}{ High } \\
\hline & & $\%$ & 0 & 3.6 & 18.2 & 36.4 & 41.8 & 100 & & & & & & \\
\hline \multirow[b]{2}{*}{3} & \multirow{2}{*}{$\begin{array}{l}\text { Efficiency of } \\
\text { Excavation } \\
\text { machines }\end{array}$} & No. & 0 & 0 & 3 & 10 & 42 & 55 & \multirow[b]{2}{*}{4.7091} & \multirow[b]{2}{*}{0.56676} & \multirow[b]{2}{*}{2} & \multirow[b]{2}{*}{47.164} & \multirow[b]{2}{*}{0.000} & \multirow{2}{*}{$\begin{array}{l}\text { Very } \\
\text { High }\end{array}$} \\
\hline & & $\%$ & 0 & 0 & 5.5 & 18.2 & 76.3 & 100 & & & & & & \\
\hline \multirow[b]{2}{*}{4} & \multirow{2}{*}{$\begin{array}{l}\text { Effect of } \\
\text { periodic } \\
\text { maintenance } \\
\text { for machines }\end{array}$} & No. & 1 & 2 & 6 & 25 & 21 & 55 & \multirow[b]{2}{*}{4.1455} & \multirow[b]{2}{*}{0.89065} & \multirow[b]{2}{*}{5} & \multirow[b]{2}{*}{45.636} & \multirow[b]{2}{*}{0.000} & \multirow[b]{2}{*}{ High } \\
\hline & & $\%$ & 1.8 & 3.6 & 10.9 & 45.5 & 38.2 & 100 & & & & & & \\
\hline \multirow[b]{2}{*}{5} & \multirow{2}{*}{$\begin{array}{l}\text { Effect of the } \\
\text { availability of } \\
\text { specialized } \\
\text { technicians }\end{array}$} & No. & 1 & 11 & 19 & 15 & 9 & 55 & & & & & & \\
\hline & & $\%$ & 1.8 & 20.0 & 34.5 & 27.3 & 16.4 & 100 & 3.3636 & 1.04285 & 7 & 16.727 & 0.002 & Medium \\
\hline & Effect of the & No. & 3 & 7 & 19 & 18 & 8 & 55 & & & & & & \\
\hline 6 & $\begin{array}{l}\text { availability of } \\
\text { storage places } \\
\text { for the wastes } \\
\text { of excavation } \\
\end{array}$ & $\%$ & 5.5 & 12.7 & 34.6 & 32.7 & 14.5 & 100 & 3.3818 & 1.06268 & 6 & 18.364 & 0.001 & Medium \\
\hline & Availability & No. & 0 & 1 & 8 & 26 & 20 & 55 & & & & & & \\
\hline 7 & $\begin{array}{l}\text { machines to } \\
\text { remove } \\
\text { wastes from } \\
\text { the excavated } \\
\text { site }\end{array}$ & $\%$ & 0 & 2 & 15 & 47 & 36 & 100 & 4.1818 & 0.74761 & 3 & 27.982 & 0.000 & High \\
\hline
\end{tabular}

The analysis of data for the factor "Geological nature of the site" is shown in Table 9. This table indicated that the Chi-Square test is statistically significant for all elements (where the p- 
value is less than 0.05). This shows that there are significant differences in responses toward elements. Therefore, the results of this group can be generalized to the study population.

Table 9: Responses Towards "Geological Nature of the Site"

\begin{tabular}{|c|c|c|c|c|c|c|c|c|c|c|c|c|c|c|}
\hline$\dot{\mathbf{Z}}$ & 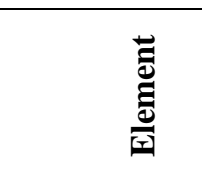 & & $\frac{3}{2}=$ & 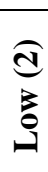 & 急 & $\begin{array}{l}\text { 于 } \\
\frac{5}{60} \\
.9\end{array}$ & $\frac{2}{30}$ & हैं & 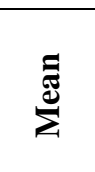 & 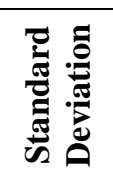 & 象 & 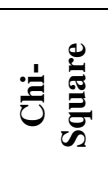 & 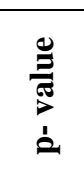 & : \\
\hline \multirow[t]{2}{*}{1} & $\begin{array}{l}\text { Types of } \\
\text { geological }\end{array}$ & No & 1 & 2 & 7 & 21 & 24 & 55 & \multirow{2}{*}{4.1818} & \multirow{2}{*}{0.92478} & \multirow{2}{*}{1} & \multirow{2}{*}{42.364} & \multirow{2}{*}{0.000} & \multirow{2}{*}{ High } \\
\hline & formations & $\%$ & 1.8 & 3.6 & 12.7 & 38.2 & 43.6 & 100 & & & & & & \\
\hline \multirow{2}{*}{2} & \multirow{2}{*}{$\begin{array}{l}\text { Suitability of } \\
\text { soil layers for } \\
\text { the intended } \\
\text { project }\end{array}$} & No & 1 & 2 & 13 & 20 & 19 & 55 & \multirow{2}{*}{3.9818} & \multirow{2}{*}{0.95240} & \multirow{2}{*}{3} & \multirow{2}{*}{30.000} & \multirow{2}{*}{0.000} & \multirow{2}{*}{ High } \\
\hline & & $\%$ & 1.8 & 3.6 & 23.6 & 36.4 & 34.5 & 100 & & & & & & \\
\hline \multirow[t]{2}{*}{3} & \multirow{2}{*}{$\begin{array}{l}\text { Existence of } \\
\text { problematic soil } \\
\text { layers at the site }\end{array}$} & No & 3 & 2 & 7 & 20 & 23 & 55 & \multirow[t]{2}{*}{4.0545} & \multirow[t]{2}{*}{1.09575} & \multirow[t]{2}{*}{2} & \multirow[t]{2}{*}{35.091} & \multirow[t]{2}{*}{0.000} & \multirow[t]{2}{*}{ High } \\
\hline & & $\%$ & 5.5 & 3.6 & 12.7 & 36.4 & 41.8 & 100 & & & & & & \\
\hline
\end{tabular}

The analysis of data for the factor "Project site investigation" shown in Table 10. This table indicates that the Chi-Square test is statistically significant for all elements (where the p-value is less than 0.05). This shows that there are significant differences in responses towards elements. Therefore, the results of this group can be generalized to the study population.

Table 10: Responses Towards " Site Investigation for Projects "

\begin{tabular}{|c|c|c|c|c|c|c|c|c|c|c|c|c|c|c|}
\hline$\dot{z}$ & & & 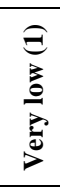 & $\begin{array}{l}0 \\
\vdots \\
0 \\
0 \\
1\end{array}$ & 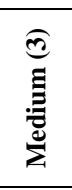 & 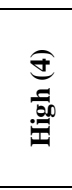 & 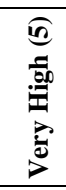 & $\stackrel{\frac{\pi}{0}}{\theta}$ & $\stackrel{\Xi}{\Sigma}$ & 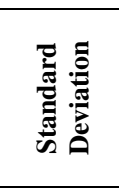 & 最 & 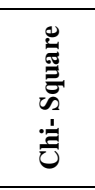 & 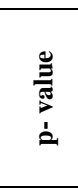 & : \\
\hline \multirow{2}{*}{1} & \multirow{2}{*}{$\begin{array}{l}\text { The availability of } \\
\text { a documented site } \\
\text { investigation for } \\
\text { the project }\end{array}$} & No & 3 & 1 & 4 & 16 & 31 & 55 & \multirow{2}{*}{4.2909} & \multirow{2}{*}{1.06585} & \multirow{2}{*}{1} & \multirow{2}{*}{58.000} & \multirow{2}{*}{0.000} & \multirow{2}{*}{$\begin{array}{l}\text { Very } \\
\text { High }\end{array}$} \\
\hline & & $\%$ & 5.5 & 1.8 & 7.3 & 29.1 & 56.4 & 100 & & & & & & \\
\hline \multirow{2}{*}{2} & \multirow{2}{*}{$\begin{array}{l}\text { Effect of land } \\
\text { slides for the } \\
\text { ajacent buildings } \\
\text { and utilities }\end{array}$} & $\begin{array}{c}\text { No } \\
\text {. }\end{array}$ & 2 & 3 & 7 & 25 & 18 & 55 & \multirow{2}{*}{3.9818} & \multirow{2}{*}{1.00905} & \multirow{2}{*}{6} & \multirow{2}{*}{36.909} & \multirow{2}{*}{0.000} & \multirow{2}{*}{ High } \\
\hline & & $\%$ & 3.6 & 5.5 & 12.7 & 45.5 & 32.7 & 100 & & & & & & \\
\hline \multirow[t]{2}{*}{3} & \multirow{2}{*}{$\begin{array}{l}\text { Effect of side } \\
\text { collapse at the } \\
\text { project site }\end{array}$} & No & 2 & 2 & 4 & 20 & 27 & 55 & \multirow{2}{*}{4.2364} & \multirow{2}{*}{0.99933} & \multirow{2}{*}{4} & \multirow{2}{*}{49.818} & \multirow{2}{*}{0.000} & \multirow{2}{*}{$\begin{array}{l}\text { Very } \\
\text { High }\end{array}$} \\
\hline & & $\%$ & 3.6 & 3.6 & 7.3 & 36.4 & 49.1 & 100 & & & & & & \\
\hline \multirow[t]{2}{*}{4} & \multirow{2}{*}{$\begin{array}{l}\text { The existence of } \\
\text { faults below } \\
\text { foundations }\end{array}$} & $\begin{array}{c}\text { No } \\
.\end{array}$ & 2 & 10 & 12 & 25 & 6 & 55 & \multirow[t]{2}{*}{3.4182} & \multirow[t]{2}{*}{1.03084} & \multirow[t]{2}{*}{9} & \multirow[t]{2}{*}{27.636} & \multirow[t]{2}{*}{0.000} & \multirow[t]{2}{*}{ Medium } \\
\hline & & $\%$ & 3.6 & 18.2 & 21.8 & 45.5 & 10.9 & 100 & & & & & & \\
\hline 5 & Effect of caves & $\begin{array}{c}\text { No } \\
\text {. }\end{array}$ & 5 & 4 & 16 & 22 & 8 & 55 & 3.4364 & 1.11826 & 8 & 21.818 & 0.000 & High \\
\hline & & $\%$ & 9.1 & 7.3 & 29.1 & 40.0 & 14.5 & 100 & & & & & & \\
\hline 6 & $\begin{array}{l}\text { The appearance of } \\
\text { groudwater during }\end{array}$ & No & 3 & 1 & 9 & 25 & 17 & 55 & 39455 & 102593 & 7 & 36364 & 0000 & Hioh \\
\hline & $\begin{array}{l}\text { performing the } \\
\text { excavation }\end{array}$ & $\%$ & 5.5 & 1.8 & 16.4 & 45.5 & 30.9 & 100 & 5.340 & & & & & 1110 \\
\hline 7 & $\begin{array}{l}\text { Referring to } \\
\text { "items 2-6" in the }\end{array}$ & No & 4 & 1 & 4 & 13 & 33 & 55 & 42727 & 116107 & 2 & 62364 & 0000 & Very \\
\hline 1 & $\begin{array}{l}\text { site investigation } \\
\text { report. }\end{array}$ & $\%$ & 7.3 & 1.8 & 7.3 & 23.6 & 60.0 & 100 & 4.2121 & ו & 2 & 02.504 & 0.000 & High \\
\hline & $\begin{array}{l}\text { The availability of } \\
\text { solutions to "items }\end{array}$ & No & 1 & 1 & 5 & 24 & 24 & 55 & & & & & & \\
\hline 8 & $\begin{array}{l}2-6 " \text { in the site } \\
\text { investigation } \\
\text { report }\end{array}$ & $\%$ & 1.8 & 1.8 & 9.1 & 43.6 & 43.6 & 100 & 4.2545 & 0.84367 & 3 & 52.182 & 0.000 & $\begin{array}{l}\text { Very } \\
\text { High }\end{array}$ \\
\hline & $\begin{array}{l}\text { Effect of using the } \\
\text { solutions }\end{array}$ & No & 3 & 1 & 3 & 22 & 26 & 55 & & & & & & \\
\hline 9 & $\begin{array}{l}\text { mentioned in the } \\
\text { previous item at } \\
\text { the proper time }\end{array}$ & $\%$ & 5.5 & 1.8 & 5.5 & 40.0 & 47.3 & 100 & 4.2182 & 1.03084 & 5 & 52.182 & 0.000 & High \\
\hline
\end{tabular}


The analysis of data for the factor "Technical expertise specialized in carrying out excavation works and other personnel" is shown in Table 11. This table indicates that the ChiSquare test is statistically significant for all items (where the p-value is less than 0.05) except that for element (3) (effect of laboratory tests when performing excavation work, if requested). In general this shows that there are general significant differences in responses toward elements. Therefore, the results of this group can be generalized to the study population.

Table 11: Responses Towards "Technical expertise in carrying out excavation works"

\begin{tabular}{|c|c|c|c|c|c|c|c|c|c|c|c|c|c|c|}
\hline$\stackrel{\dot{Z}}{\mathbf{Z}}$ & 를 & & $\frac{a}{3}$ & 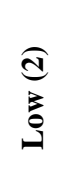 & 点 & 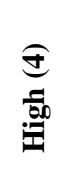 & 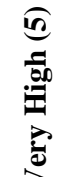 & है & 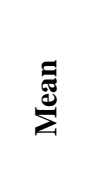 & 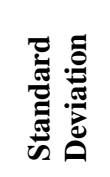 & 点 & 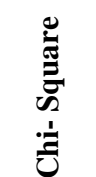 & 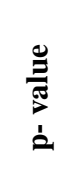 & تِّ: \\
\hline \multirow[b]{2}{*}{1} & \multirow{2}{*}{$\begin{array}{l}\text { Effect of } \\
\text { recruiting } \\
\text { experienced } \\
\text { people in } \\
\text { carrying out } \\
\text { excavation } \\
\text { work }\end{array}$} & No & 2 & 7 & 16 & 17 & 13 & 55 & & & & & & \\
\hline & & $\%$ & 3.6 & 12.7 & 29.1 & 30.9 & 23.6 & 100 & 3.5818 & 1.10035 & 4 & 14.727 & 0.005 & High \\
\hline \multirow[b]{2}{*}{2} & \multirow{2}{*}{$\begin{array}{l}\text { The relationship } \\
\text { between the } \\
\text { supervising } \\
\text { company and } \\
\text { the carrying out } \\
\text { company }\end{array}$} & $\begin{array}{c}\text { No } \\
\text {. }\end{array}$ & 0 & 6 & 22 & 17 & 10 & 55 & & & & & & \\
\hline & & $\%$ & 0 & 10.9 & 40.0 & 30.9 & 18.2 & 100 & 3.5636 & 0.91820 & 5 & 11.109 & 0.011 & High \\
\hline \multirow[b]{2}{*}{3} & \multirow{2}{*}{$\begin{array}{l}\text { Effect of } \\
\text { laboratory tests } \\
\text { during } \\
\text { performing } \\
\text { excavation } \\
\text { work, if } \\
\text { requested }\end{array}$} & $\begin{array}{c}\text { No } \\
\text {. }\end{array}$ & 0 & 8 & 19 & 18 & 10 & 55 & & & & & & \\
\hline & & $\%$ & 0 & 14.5 & 34.5 & 32.7 & 18.2 & 100 & 3.5455 & 0.95874 & 6 & 6.745 & 0.080 & High \\
\hline \multirow{2}{*}{4} & \multirow{2}{*}{$\begin{array}{l}\text { Effect of the } \\
\text { presence of } \\
\text { surveyors at the } \\
\text { excavated site }\end{array}$} & $\begin{array}{c}\text { No } \\
\text {. }\end{array}$ & 1 & 6 & 21 & 18 & 9 & 55 & \multirow{2}{*}{3.5091} & \multirow{2}{*}{0.95980} & \multirow{2}{*}{7} & \multirow{2}{*}{25.273} & \multirow{2}{*}{0.000} & \multirow{2}{*}{ High } \\
\hline & & $\%$ & 1.8 & 10.9 & 38.2 & 32.7 & 16.4 & 100 & & & & & & \\
\hline \multirow[t]{2}{*}{5} & \multirow{2}{*}{$\begin{array}{l}\text { The efficiency } \\
\text { of carrying out } \\
\text { company }\end{array}$} & $\begin{array}{c}\text { No } \\
\text {. }\end{array}$ & 0 & 6 & 10 & 17 & 22 & 55 & \multirow[t]{2}{*}{4.000} & \multirow[t]{2}{*}{1.01835} & \multirow[t]{2}{*}{1} & \multirow[t]{2}{*}{11.109} & \multirow[t]{2}{*}{0.011} & \multirow[t]{2}{*}{ High } \\
\hline & & $\%$ & 0 & 10.9 & 18.2 & 30.9 & 40.0 & 100 & & & & & & \\
\hline \multirow[b]{2}{*}{6} & \multirow{2}{*}{$\begin{array}{l}\text { Effect of } \\
\text { previous } \\
\text { experiences for } \\
\text { the carying out } \\
\text { company }\end{array}$} & $\begin{array}{c}\text { No } \\
\text {. }\end{array}$ & 1 & 3 & 13 & 23 & 15 & 55 & \multirow[b]{2}{*}{3.8727} & \multirow[b]{2}{*}{0.94388} & \multirow[b]{2}{*}{2} & \multirow[b]{2}{*}{29.818} & \multirow[b]{2}{*}{0.000} & \multirow[b]{2}{*}{ High } \\
\hline & & $\%$ & 1.8 & 5.5 & 23.6 & 41.8 & 27.3 & 100 & & & & & & \\
\hline \multirow[t]{2}{*}{7} & \multirow{2}{*}{$\begin{array}{l}\text { The preparation } \\
\text { for the } \\
\text { excavation } \\
\text { works }\end{array}$} & $\begin{array}{c}\text { No } \\
.\end{array}$ & 2 & 3 & 17 & 20 & 13 & 55 & \multirow{2}{*}{3.7091} & \multirow{2}{*}{1.01238} & 3 & 24.182 & 0.000 & High \\
\hline & & $\%$ & 3.6 & 5.5 & 30.9 & 36.4 & 23.6 & 100 & & & & & & \\
\hline
\end{tabular}

The analysis of data for the factor "Financial liquidity and the payment of dues" is shown in Table 12. This table indicates that the Chi-Square test is statistically significant for all elements (where the p-value is less than 0.05). This shows that there are significant differences in responses toward elements. Therefore, the results of this group can be generalized to the study population. 
Table 12: Responses Towards "Financial Liquidity and the Payment of Dues"

\begin{tabular}{|c|c|c|c|c|c|c|c|c|c|c|c|c|c|c|}
\hline$\dot{\mathbf{z}}$ & \multicolumn{2}{|l|}{ 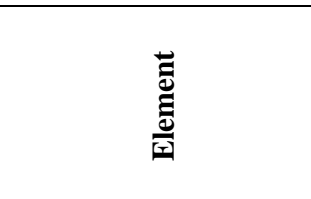 } & $\frac{\widehat{\Xi}}{\frac{3}{0}}$ & 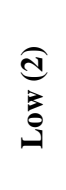 & 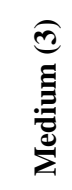 & 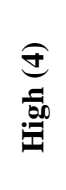 & 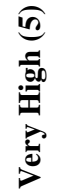 & हैं & 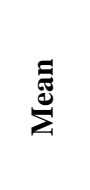 & 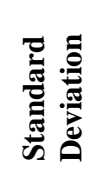 & 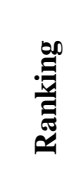 & 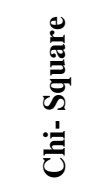 & $\begin{array}{l}\frac{9}{E} \\
\frac{\pi}{2} \\
\dot{2}\end{array}$ & E \\
\hline \multirow[b]{2}{*}{1} & \multirow{2}{*}{$\begin{array}{l}\text { Making payments } \\
\text { for excavation } \\
\text { works according to } \\
\text { the stipulated dates } \\
\text { and agreements }\end{array}$} & No. & 3 & 4 & 10 & 18 & 20 & 55 & \multirow[b]{2}{*}{3.8727} & \multirow[b]{2}{*}{1.15557} & \multirow[b]{2}{*}{1} & \multirow[b]{2}{*}{22.182} & \multirow[b]{2}{*}{0.000} & \multirow[b]{2}{*}{ High } \\
\hline & & $\%$ & 5.5 & 7.3 & 18.2 & 32.7 & 36.4 & 100 & & & & & & \\
\hline \multirow[b]{2}{*}{2} & \multirow{2}{*}{$\begin{array}{l}\text { Effect of changing } \\
\text { the fuel and oil } \\
\text { prices }\end{array}$} & No. & 4 & 7 & 13 & 19 & 12 & 55 & \multirow[b]{2}{*}{3.5091} & \multirow[b]{2}{*}{1.18435} & \multirow[b]{2}{*}{3} & \multirow[b]{2}{*}{12.182} & \multirow[b]{2}{*}{0.016} & \multirow[b]{2}{*}{ High } \\
\hline & & $\%$ & 7.3 & 12.7 & 23.6 & 34.5 & 21.8 & 100 & & & & & & \\
\hline \multirow[b]{2}{*}{3} & \multirow{2}{*}{$\begin{array}{l}\text { Paying incentives } \\
\text { to the workers at } \\
\text { the project site }\end{array}$} & No. & 0 & 3 & 25 & 15 & 12 & 55 & \multirow{2}{*}{3.6545} & \multirow[b]{2}{*}{0.88649} & \multirow[b]{2}{*}{2} & \multirow[b]{2}{*}{17.945} & \multirow[b]{2}{*}{0.000} & \multirow[b]{2}{*}{ High } \\
\hline & & $\%$ & 0 & 5.5 & 45.5 & 27.3 & 21.8 & 100 & & & & & & \\
\hline
\end{tabular}

\section{SUMMARY OF RESULTS}

The analysis was mainly focused on chi-square goodness of fit test that indicated statistically significant differences between the observed and expected responses towards most factors (in which p-values are less than 0.05) except that for few elements. Accordingly, the analyses for this study confirmed that the alternative hypothesis (H1) is accepted (i.e., there is a real problem faced by a large part of construction projects in Jordan concerning the productivity of excavation works). Therefore, the factors mentioned before could be considered as the major factors affecting the productivity of excavation works in Jordan.

\section{CONCLUSIONS}

Referring to the results of this investigation, the following conclusions are drawn:

- Several major factors affect the productivity of excavation works in construction projects. In this research, five factors were proposed, evaluated, and concluded to be the most major factors that could influence the productivity of excavation works for construction projects in Jordan, and could significantly affect the cost and time of carrying out the project. These five factors were arranged sequentially depending on the level of its importance.

- "The availability and readiness of the excavation machines at the project site" is considered the first major factor that could strongly affects the productivity of excavation works in Jordanian construction projects, and generally could be regarded as one of the main factors that contribute to the success and continuity of the project excavation works. Moreover, "The existing geological formations at the project site" (such as types of soil or rock layers and their sequence, the seismic properties of the site, the existing of caves or cavities, etc.), are considered the main second factor that affects the productivity of excavation works in projects and may influence the time and cost needed to complete the required project.

- The importance of performing "Site investigations for the proposed project" and the existence of "technical expertise in carrying out excavation work" are considered the main third and fourth factors that affect the productivity of excavation works in construction projects. Hence, before starting an excavation work in a construction project, it is required to obtain a well-documented site investigation. In general, this investigation shall include several sections that focused on studying the possibility of facing problematic soil layers, mass movements at the study site or that for adjacent areas, existing of ground water and its depth (if any), the climate of the site, etc. However, these elements may also strongly affect the productivity of excavation work in construction projects. Therefore, to avoid problems during the execution of excavation processes, the necessary precautions to the above elements must be taken into account. 
- The fifth main factor that affects the productivity of excavation works for construction projects in Jordan is the availability of "financial liquidity and the payment of dues". Hence, the effect of this factor will contribute to preventing the delay in completion of the required work, and preventing any increase in time and cost.

\section{REFERENCES}

[1] Ahmed H., (2017). "Construction Risk Management of Deep Braced Excavations in Cairo". Australian Journal of Basic and Applied Science, Volume 1, Issue 4, 506-518.

[2] Aibinu, A. A and Odeyinka, H. A. (2006). "Construction delays and their causative factors in Nigeria". Journal of Construction Engineering and Management ASCE 132(7): 667-677.

[3] Agha. B., (2017). "Factors relating to labor productivity" 12th East Asia-Pacific on Structural Engineering" No. 47.

[4] Al-Abbadi G., and Mensah G., (2019). "The effects of motivational factors on construction professional's productivity in Jordan". International Journal of Construction Management, DOI: 10.1080/15623599.2019.1652951.

[5] AL-Kharabsheh N., (2017)."Risk Management of Executing Deep Excavations of Large-Scale Projects and Controlling their Wastes in Jordan", Vol 7 No. 8: 144-151.

[6] Assaf A. and Al-Hejji S., (2005). "Causes of Delay in Large Construction Projects", International Journal of Project Management, Vol.24(2006): 349-357.

[7] Deshmukh A. and Parag S., (2016). "Factors Affecting Performance of Excavating Equipment: An Overview". International Journal of Science and Research (IJSR). 5(1).

[8] Gascueña N. et al., (2011). "Factors that Affect the Productivity of Construction Projects in Small and Medium Companies: Analysis of its Impact on Planning ", in: Egbu, C. and Lou, E.C.W. (Eds.) Procs 27th Annual ARCOM Conference, 5-7 September 2011, Bristol, UK, Association of Researchers in Construction Management, 879-888.

[9] Goodrum M. and Gangwar M., (2010). "The relationship between changes in equipment technology and wages in the US construction industry", (Safety Incentives: A study of their effectiveness in construction). Vol.22 (3) p. 291-301.

[10] Hafez Sh. et al., (2014). "Critical factors affecting construction labor productivity in Egypt". American Journal of Civil Engineering. Vol. 2, No. 2, 2014, pp. 35-40.

[11] Islam S., Trigunarsyah B. and Assaf A., (2015). "Causes of Delay in Construction Projects in Bangladesh". ICCEPM. ISBN 978-89-954572-6-9.

[12] Kalokhe B., Sarode C. and Warke S., (2019). "Evaluating Excavation Equipment Productivity Constant for Construction Project". International Journal of Innovative Research in Science, Engineering and Technology, Vol.8, Issue 2.

[13] Kazaz A. Ulubeyli S. and Tuncbilekl A., (2012). "Causes of Delays in Construction Projects in TURKEY". Journal of Construction Engineering and Management, VOL18(3): 426-435.

[14] Mahamid I., (2013). "Principal Factors Impacting Labor Productivity of Public Construction Projects in Palestine: Contractors' Perspective". IJAEC. Volume 2, 194-202.

[15] Masood R., (2015). "Investigating the Delay Factors of Construction Projects in Metropolitan City of a Developing Country". Civil Eng. Architect. Res. Vol. 2, No. 9, pp. 947-955.

[16] Prasad S. and Rechunath K, (2010). "Empirical Analysis of Construction Safety Climate". International Journal of Engineering Science and Technology. Vol. 2(6), 1699-1707.

[17] Razuri C., Alarcon F. and Diethelm S., (2007). "Evaluating the Effectiveness of Safety Managing Practices and Strategies in Construction Projects". Proceedings IGLC-15, July 2007, Michigan, USA, p.591-698. 
Orabi Al Rawi, Ibrahim Farouq Varouqa, Ra'ed Al-muhanna and Ala’ Diab Amer

[18] Richard P., (2012). "Earth Pressure and Retaining Wall Basics for Non-Geotechnical Engineers". PDH Centre (professional development hours), USA.

[19] Sweis J., (2013). "Key Factors Impact on public sector employee productivity in Saudi Arabia Construction Projects". International Journal of Civil Works Environmental Engineering, Vol. 14, No.1. 16-20.

[20] Zaher M., (2015). "Important factors that affect the productivity of excavation work in construction projects". Vol. 18, No.4. 14-28. 